\title{
JUURNAL.RU
}

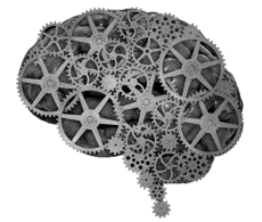

COMPANY GROUP "INTELLEKT"

Вербицкий Р.Ю. Московский гуманитарно-экономический институт «Автономная некоммерческая организаиия высшего профильного образования МГЭИ»

Москва, Россия

doi: 10.18411/lj2016-6-1-03

\section{Тенденция развития концепции социальных представлений в социальной психологии}

Уже на протяжении полу века теория социальных представлений французского социального психолога С.Московиси[1], переросшая в концепцию, продолжает развиваться с нарастающей силой. $\mathrm{C}$ момента появления самого понятия «социальные представления», в западной Европе не угасают дискуссии относительно структуры указанной категории, методов исследования и т.д.Стоит отметить, что у концепции большое количество последователей, которые отмечают положительные ее стороны, однако существует и объективная критика.

В отечественной социальной психологии данная концепция многократно становилась объектом теоретического анализа.Большинство отечественныхученых смотрят на категорию социальные представления под различными углами. Кроме этого накоплен огромный объём исследований в современном российском обществе. Все это развивает концепцию социальных представлений, придавая ей все больший интерес ученых и ученых-любителей.

Настаивая на идеи о становлении социальных представлений как предмета социальной психологии в будущем[2], благодаря функции решения проблем общества, мы провели свое социально-психологическое исследование. Исследуя социальные представления российской молодежи о политической конкуренции, 
мы выяснили, что в их содержании закреплена информация о недобросовестной политической конкуренции [3]. Кроме прочих данных и подтвержденных гипотез, выявленное содержание, как основной результат, лег в основу оформления практических рекомендаций по управлению изучаемыми представлениями. Добавим, что согласно результатам исследования указанные представления имеют высокий уровень согласованности в молодежной среде.

Особенно отметим эффективность параллельного использования методов анкетирования, интервью и фокус-групп, где анкетный опрос использован как основной метод исследования.

Таким образом, наше исследование становится еще одним плюсом в развитии концепции социальных представлений, и дополнительно подтверждает тенденцию развития социальной психологии.

\section{Литература:}

1. Moscovici S. La psychoanalyse, son image et son public. - Paris: Presses Universitaires de France, 1961. - 650 p.

2. Вербицкий Р.Ю. Социальные представления как предмет социальной психологии. // Вестник Университета ГУУ. - 2015. №11. - С.311-315.

3. Вербицкий Р.Ю. Результаты исследования социальных представлений российской молодежи о политической конкуренции / Р.Ю. Вербицкий // Казанский педагогический журнал. - 2016. - №2, Ч.2.- С.404-409. 